\title{
Crisis Management: Suggestions on How Mandalay Bay Can Survive Disaster
}

\author{
Daniel Boylan \\ Purdue University, Fort Wayne \\ Rachel Greenawalt \\ Widener University
}

Acts of terror are intended to incite fear and intimidation, which makes the hospitality industry susceptible to attacks. This research explores the impact of terrorist attacks on the hospitality industry including hotels, restaurants, and night clubs/pubs. The financial burdens and impact on the reputation are long lasting. This risk makes understanding ways to rebound from tragic events critical. To conduct this research information was gathered on terrorist attacks on hotels and then separately for restaurants/pubs. Information regarding the hotels name, location, year of event and number of deaths were gathered from 2002 to 2017. Additionally, research was conducted to determine how each event was responded to. The research found that nearly the same number of deaths occurred across the shorter time frame studied for hotels compared to restaurants but hotels rebounded better financially after an event. It is clear that terrorist attacks will continue to target the hospitality industry necessitating a well-trained management team, open communication and coordination plans with local emergency teams, and the need to improve overall security.

Keywords: crisis management, strategy, financial survival, rebranding, terrorism, hospitality industry

\section{INTRODUCTION}

Vacations are a special time for many individuals and families. Tourists find excitement in exploring new places, relaxing, and creating new memories. Travel can prove to be some of the most positive exuberant times of one's life. Within a couple of minutes, the positive memory can turn negative due to an act of violence. Being involved in or near a terrorist attack can change one's life forever. Though most of the memories from a trip could be positive, one negative experience can overshadow the occasion and command those same people to rethink travel for the rest of their lives (Stickel, 2011).

An increasing occurrence of terrorism over time is now a major concern for all hospitality owners and managers, resulting in extensive training and increased security (Leggat, Mills, \& Speare, 2007). The tourism and hospitality management industry includes hotels, nightclubs, restaurants, and casinos. All of these parts are prone to attacks by terrorists. The physical result of sabotage includes extensive property damage and personal injuries and deaths. Less obvious damage includes the inability to use the facilities, loss of customer goodwill, and an implied inability to maintain the well-being of the public as well as 
national attention for a negative reason (Stickel, 2011). One negative event can affect the entire tourism and hospitality industry. This typically takes the form of either a decrease in spending or a decline in travel.

Since 2000, 140,000 people have been killed and over 61,000 terrorist attacks have been committed (Koroma, 2011). Common first steps after an attack are recognizing decreased sales (Stickel, 2011), then and try to reduce operating costs and enhance security (Abatemarco, Beckley, Borjan, \& Robson, 2007). The next steps include working to build back sales and repair the organization's image. For hotels, it is important to cut costs where applicable while not decreasing the quality of service experienced by guests (Stickel, 2011).

Tragedy can come at the most unexpected times and change the reputation or the fate of the company forever. When terrorist attacks happen, businesses must take different approaches and be proactive rather than reactive. Reactive responses from companies can cause financial difficulties or even loss of the business altogether. Both of these burdens are owners and managers' worse nightmares making the way terrorism is prepared for and handled to the fate of the owners (Stickel, 2011). For a city, the result can be equally devastating. A small decrease in tourism dollars can result in immediate layoffs of thousands of workers (Glaeser \& Shapiro, 2001).

This research paper analyzes the incident of terrorist acts, various strategies used to address the effect of terrorism on both tourism and the hospitality industry, and how or if these businesses recover after an act. This analysis recognizes terrorism diminishes the goal of a vacation by increasing the likelihood of danger (Karoma, 2011). Two questions will be addressed. The first is can suggestions be made to help MGM Resorts International decide strategies following the mass shooting at its Mandalay Bay Resort and Casino located in Las Vegas to survive? The second question is "can the hospitality industry apply these strategies in the future?"

The main components of domestic terrorism include violence, private purposes, an intent of scaring people, and political aims (U. S. Code, 2017). Specifically, the U.S. Code 18 USC $§ 2331(5)$ defines the term "domestic terrorism" as an activity that:

First, involves acts dangerous to human life that violations criminal laws of either the federal government or any individual State; and

Second, appears to be intended to:

1. intimidate or coerce a civilian population;

2. influence the policy of a government by intimidation or coercion; or

3. affect the conduct of a government by mass destruction, assassination, or kidnapping; and

Third, occurs mainly within the territorial jurisdiction of the United States (U.S. Code, 2017). This phenomenon has a deep impact. Not only is there a stain on a city's reputation, but the impact can also be felt by retailers, loss of tax revenues, and a decrease in hotel occupancy. Its impact on financial resiliency, government regulations, and society affects everyone in one way or another (Karoma, 2011).

The balance of this work is organized into the following four sections. First, a literature review looks at prior literature that informs this study. The next section includes methodology, including both the research question and experiment design. The third section includes the research findings. Finally, the research ends with conclusions, including limitations and future research.

\section{LITERATURE REVIEW}

On October 2, 2017, the largest mass shooting in United States history by an individual occurred from the $32^{\text {nd }}$ floor in room 135 of the Mandalay Bay Casino and Resort in Las Vegas, Nevada. Stephen Paddock's actions killed 58 and injured 546 individuals. The victims were located in an outdoor venue enjoying the Route 91 Harvest Festival (Palazzolo \& Elinson, 2017). Mr. Paddock fired approximately 1,100 rounds of ammunition out of his hotel room window to a crowd listening to Country music artist Jason Aldean. When officers arrived at room 135 they found a room filled with automatic rifles and surveillance equipment. The scene finally ended with Mr. Paddock taking his own life in the same room (Taylor, 2017). The event left the nation and the world stunned. 
The result of this event was devastating to Mandalay Bay's stock price. The hotel suffered a $\$ 909$ million market capitalization that decreased from $\$ 18.7$ billion to $\$ 17.8$ billion on the Monday following the incident. Major investors were also shedding the stock in fear of market declines the Monday following the shooting. The impact was a 5\% decrease in stock price (Shan, 2017).

In this scenario, there are two sources at fault for this act of terrorism. The most prominent one being Stephen Paddock, a 64-year-old male now responsible for the deadliest mass shooting in United States history by a lone gunman. But also the Mandalay Bay Resort and Casino. There has been no direct blame put on the resort because there is no evidence of them being behind the shooting. Questions arise on how Paddock transported 23 rifles into his hotel room without security or housekeeping noticing (Craig, Berman, Barrett, \& Zapotosky, 2017).

The actions of communities are moving from one of response to prevention and working to develop knowledge supporting interference at an earlier stage against the violent acts, especially terrorism (O'Brien, 2009). "If hotel leadership is not seen as part of the solution, they will be considered part of the problem. If they cannot engage productively, they will not influence in shaping the result of their property" (Alderman, 2016). This quote stresses if hotel managers are not connecting with local police and safety departments to find ways to work toward providing a safer environment for tourists, then decisions on how they must improve safety will be dictated. Actively participating in the decision-making processes will ensure a hotel or entertainment venue is not left without a voice in the development and implementation of improved safety measures. A goal of running a hospitality sector is preserving safety and security for all guests who choose a specific hotel as a place to stay or attend. There is, unfortunately, no way to stop all terrorism. Events like what happened at Mandalay Bay, however, lead families of victims and community members to wonder how such odd behavior was overlooked by the company in charge (Stickel, 2011).

Hotels are an accessible, public place viewed as easy to attack and easy to get public attention (Stickel, 2011). Although security measures must be put into place, companies do not want to be too restrictive as to scare away visitors. Fred Del Marva, a hospitality security expert, says the shooting in Las Vegas at Mandalay Bay was almost unpreventable. Although they could have put dogs in the front of the casino as customers walked in it would put customers on edge. He explains that hotels and casinos probably have the worst security of any industry sighting it is because they are reactive instead of proactive (Bartimomo, 2017).

Putting plans in place will start to frustrate terrorists and interfere with their planning at an earlier stage. It can also allow communities to detect terrorist plotting in and around potential targets. In the early stages, the goal is to ward off terrorists by letting it be known that each specific location is under watch and high security. Each hotel is responsible for its attacks and to be sure it is doing as much as possible to protect the guests in and around the property (Karoma, 2011).

Marriot CEO Arne Sorenson said, "We live in a risky world, we run hotels which are meant to welcome people, they're not hard targets if you will, but we do pay attention to security threats, we talk with the authorities around the world, and we have threat condition levels. When risks are up, we have more elaborate security procedures in place" (Hoenemeyer, 2016). For instance, in the Philippines, 36 people died of smoke inhalation and suffocation, and 50 were injured in one of the worst terrorist attacks in Philippines history (Ross, 2017). This shows the prevalence of the rising threat of terrorism.

After the attacks in Paris in April of 2015, Europe had a zero percent growth rate. Many hotels were forced to lay off employees and cut costs to still attract some visitors. In Europe, tourism makes up about $10 \%$ of economic activity. Tourism has decreased roughly $70 \%$ and to this day, they have not had a full recovery. This shows how important it is to be preventative for attacks (Alderman, 2016).

The massive attack in Mandalay bay caused the short-term dip in tourists which is because of the obvious reasons. Also, the stock prices of the main Las Vegas casino companies had to face a minor downfall after the shooting. An Analyst of Morgan Stanley predicted the shooting would decrease demand for the Las Vegas market for about six months and have a $4 \%$ to $6 \%$ economic effect (Cano, 2017). According to the Las Vegas Convention and Visitors Authority CEO Rossi Ralenkotter, "There's going to be a time when we go back to promoting Las Vegas as the greatest destination in the world, but that's not now. We need to take care of this, we need to take care of our customers, we need to take care of the 
community itself, and that's what we will be doing" (Cano, 2017). The incident not only affected the visitors but also, the employees of Mandalay Bay. They started laying off workers because of the economic condition after the shooting (Moore, 2017).

The physical damage attacks can cause are issues of growing concern for cities and resorts. Learning from other urban responses to incidents improves the planning to prevent future incidents. Strategic measures were taken by cities typically cover a nine-month time frame following an attack. This is deemed the normal time for recovery to happen (Viola, 2018).

This research looks into the response of several cities with experience terrorism. These cities include New York City, Orlando, and Las Vegas. Each of these cities has a tourism not-for-profit working to enhance the areas hospitality industry while individual hotels work to enhance themselves. As a result, it is important to see the actions of the hospitality industry's partners and their marketing efforts.

Findings from Kitchen (2001), determined what was learned from New York City's response to radicalism is a predetermined plan is inadequate. Instead, the strategy used by the New York Police Department and the Federal Bureau of Investigation coevolved over the response period (Kitchen, 2001).

Smart planning was able to circumvent disaster in Orlando after the Pulse Nightclub shooting. In Orlando, the city experienced a three-percent increase in tourism. This was achieved using a multipronged approach focusing on the needs and expectations of tourists. Visit Orlando, the city's tourism marketing agency used three major strategies. These strategies include the concentration on convention travel, targeting specific countries, and focusing on domestic ads and social media on "emotional connections" and "creating memories" (Voice of America, 2017). Part of the social media effort involved encouraging recent or future tourists to post pictures showing them enjoying the city or signaling they still plan to attend despite the tragedy (Montero, 2017).

Las Vegas is not waiting on responding. Thus far, the city has temporarily dropped the decades-old slogan "What happens in Vegas, stays in Vegas" for slogans focusing on "first responders" and "strength." (Montero, 2017). Las Vegas also is capitalizing on the Orlando experience by using social media to provide emotional connections to the city. Many of the social media post feature individuals "vowing to come to Las Vegas" while others state "how important the Las Vegas is to them." The National Football League even supported the city when the Oakland Raiders, a team scheduled to move to Las Vegas, donned \#VegasStrong on their helmets (Montero, 2017).

\section{TABLE 1 \\ LIST OF HOTELS ATTACHED BY TERRORISTS FROM MANDALAY BAY TO PRESENT TIME}

\begin{tabular}{llll}
\hline Hotel & City, Country & Year & Deaths \\
\hline Mandalay Bay & Las Vegas, Nevada USA & 2017 & 58 \\
Kabul Intercontinental (2) & Kabul, Afghanistan & 2018 & 18 \\
Total & & & 76 \\
\hline
\end{tabular}

Table 1 shows there were two hotels recently. First the Mandalay Bay in 2017 in Las Vegas. The second hotel is the Kabul Intercontinental in Kabul, Afghanistan. The attack in Kabul was the second attack on this hotel and killed an estimated 18 people excluding the terrorists.

In an act of terrorism, victims often try to hold the company accountable using legal action. Here plaintiffs seek damages for harm caused including medical expenses or disabilities resulting from the shooting (Taylor, 2017). In this scenario, the hotel can choose to rebrand, go under new ownership, go bankrupt, renovate or increase its security (Feehan, 2017). One measure recently carried out on Disney properties is removing the "do not disturb" signs and need employees to inspect every room each day. The removal of the "do not disturb" signs is to ensure there isn't an expectation rooms are off-limits to property management (Matousek, 2017).

Few tourists consider the possibility of violence or terror when planning a trip. As with the attack on Paris, it becomes difficult for a hotel chain to remain reputable after falling victim to a terrorist attack. The 
theoretical framework for this research will revolve around this concept of owning a hotel chain during the attack on Paris, and a few routes the owners may pursue to handle the aftermath.

One obvious option would be to increase security. France to attract more visitors by offering discounts, increasing security measures, and reassuring safety in the city (Travel Biz Monitor, 2015). However, with this comes two questions: to what extent? And will this be enough to regain a positive reputation? An increase in security may sound like the most viable option, but could it also further hurt the company?

As stated earlier, sometimes too much security can make people feel even more anxious. Cecile Danielo, JacTravel's regional head of contracting, commented, "Families are staying away, and those who are visiting are staying for fewer nights. the picture is highly volatile with prices changing from day-today." (Canadian Travel Press, 2016). Instead of feeling safe, they feel as though there is a higher potential for danger because of the guards and surveillance. Alongside this, it creates the possibility of customers feeling like their privacy is being invaded. There is no question some security increase ought to be made after an attack has happened, but this change in itself will not wipe clean the hotel's reputation.

Another way to rebuild reputation after an attack would be to rebrand or go under new ownership. Although the company itself need not be blamed for an individual attempting violent acts, they often still are impacted. Rebranding or having new ownership could potentially put many customers and employees at ease. The thought process behind this is it could provide a higher comfortability factor if people were to think of the company in a slightly different way. For example, Apple is a company that had to rebrand and also go under new ownership with Steve Jobs in the late 1990s and did so very successfully (DeMers, 2016; Feehan, 2017).

As a last resort, hotel owners may choose or be forced to handle the situation by declaring bankruptcy. Sometimes, bankruptcy is the best option for the company, especially if all other efforts fail. The financial devastation that often comes with rebuilding a company is a large consideration. Rebranding can become very costly, and if damages from the attack are severe enough, renovation of the building may not be fiscally plausible. Harsh damages, expensive repairs, and a 25\% drop in occupancy are what caused them to file for bankruptcy and end their affiliation with Starwood (Ollila, 2016). Unfortunately for them, this is exactly what happened to the Sheraton Brussels in 2016 after the Brussels bombings.

\section{METHODOLOGY}

This research focuses on terrorist attacks, and how it affects the hospitality industry, and deciphering whether the impact of terrorist attacks makes it difficult for businesses to rebound from the incident. Though terrorism is rare, it can be difficult for a business to overcome the impact on the organization's reputation. The event will forever be a part of the organization's history (Karoma, 2011).

Two questions are addressed in this research. The first involved suggestions to help MGM Resorts International decide strategies following the mass shooting at its Mandalay Bay Resort and Casino located in Las Vegas to survive. The second question was related to applying these suggestions in the hospitality industry to help in the future.

Researchers used many tools to determine conclusions. First, researchers developed two lists of entities worldwide with experience in attacks. The first list included: hotels while the second list included: restaurants and nightclubs/pubs; city, state, country location; year; and severity as defined by the number of individuals that died. Since, terrorism is a relatively rare event, hotels throughout the world were used to develop a larger sample. Deaths were specifically used to determine impact. How many individuals were injured was not considered because of defining an injury ranging from a simple scratch to near-death (Holland, 2003). Second, researchers then searched the web to see what response these entities had to the attack to develop a conclusion on how Mandalay Bay should react.

Since little follow-up regarding business strategy exists for these entities, researchers went out to find whatever information they could on all the properties. Researchers then categorized the strategies properties used to survive. These categories include rebranding, new ownership, bankruptcy, renovations, increased security, closure, and doing nothing. 
Determining a property strategy can prove challenging. Researchers needed to make some judgment calls and rely on unconventional research strategies and searched the World Wide Web for facts. Some facts were straightforward which includes the review of web pages, newspaper articles, or online articles for information. Other evidence is difficult to prove as it is difficult to get facts in times of crisis. Eyewitness accounts are unreliable, and there is a lack of consistency in the reports generated. For example, what defines an injury? This inconsistency challenges the authenticity of reports.

Some of the research was less straightforward. For example, researchers used hotel addresses to determine if a hotel changed names, searched Google.com images to see if material renovations were completed, and reviewed travel websites such as Expedia.com to determine if a property closed permanently. Many entitle sustain substantial damage in an attack, especially if there is a bomb (Yallop, 1980). To discover if renovations were made, researchers had to determine if construction was used to replace the original structure or to "change the look" of the facility to alter its image. Researchers used the "change the look" criteria to determine renovations.

Researchers then used a compilation of these findings to develop conclusions. Given that each attack is unique to the perpetrators, location, intended targets, and possible political targets, each situation needs to be specifically analyzed based on these circumstances. Additionally, a cost factor was included as well as a prioritization of items to be implemented.

\section{FINDINGS}

This section provides the results of the research. These findings are completed by reviewing newspaper accounts, online articles, and other sources of data. Researchers often found conflicting information. When these occurred, researchers had to make a qualitative judgment or go with the data most commonly reported. The following table lists major hotel attacks by terrorists worldwide. This data includes the hotel, location, year, and numbers of deaths attributed to the incident:

TABLE 2

LIST OF HOTELS ATTACKED BY TERRORISTS WORLDWIDE

\begin{tabular}{llll}
\hline Hotel & City, Country & Year & Deaths \\
\hline Sheraton & Karachi, Pakistan & 2002 & 15 \\
J W Marriott (1) & Jakarta, Indonesia & 2003 & 12 \\
Hilton & Taba in Sinai, Egypt & 2004 & 31 \\
Grand Hyatt, Radisson, Days Inn & Amman, Jordan & 2005 & 60 \\
Hard Rock Jimbaran Bch. Resort & Bali, Indonesia & 2005 & 20 \\
Marriott & Islamabad, Pakistan & 2008 & 54 \\
Taj and Oberoi Hotels & Mumbai, India & 2008 & 166 \\
Serena (1) & Kabul, Afghanistan & 2008 & 6 \\
J W Marriott (2) and Ritz Carlton & Jakarta, Indonesia & 2009 & 7 \\
Pearl Continental & Peshawar, Pakistan & 2009 & 17 \\
Kabul Intercontinental (1) & Kabul, Afghanistan & 2018 & 12 \\
Serena (2) & Kabul, Afghanistan & 2014 & 9 \\
Radisson Blu & Bamako, Mali & 2015 & 20 \\
Riu Imperial Marhaba & Sousse, Tunisia & 2015 & 38 \\
Corinthia Hotel & Tripoli, Libya & 2015 & 10 \\
Regency Hotel & Dublin, Ireland & 2016 & 1 \\
Total & & 477 \\
\hline
\end{tabular}


Table 2 shows the list of hotels in the world that have been scenes of terrorism by location, year, and the number of deaths involved. As shown in Table 2, hotels from all over the world underwent at least one terrorist attack, in cases such as the JW Marriot and Serena, attacks happened twice. This survey gathered data including the location, the number of deaths (excluding the perpetrator(s), and the year the terrorist attack occurred. This survey recognizes in most cases, there were more injuries than deaths. The mentioned data points all contribute to perceiving how intense the attack was. It could be hypothesized perhaps one of the reasons why specific hotels were targeted is the lack of security.

From this Table, it is clear terrorist attacks are devastating. 16 incidents in 11 countries resulted in 477 deaths. The event with the least impact was at the Regency Hotel in Dublin, Ireland resulting in the death of one individual in 2016. The hardest felt event was at the Taj and Oberoi Hotels in Mumbai, India in 2008. In this attack, 166 individuals lost their lives.

Similar to Table 2, Table 3 shows the occurrence of restaurants, nightclubs, or pubs. This data includes the restaurant, location, year, and numbers of deaths attributed to the incident:

TABLE 3

\section{LIST OF RESTAURANTS AND NIGHTCLUBS/PUBS ATTACKED BY TERRORISTS WORLDWIDE}

\begin{tabular}{llll}
\hline Restaurant, Night Club or Pub & \multicolumn{1}{c}{ City, Country } & Year & Deaths \\
\hline Chez Jo Goldenberg Restaurant & Paris, France & 1982 & 6 \\
McDonald's (restaurant) & San Ysidro (San Diego), California USA & 1984 & 21 \\
Luby's Cafeteria & Killeen, Texas USA & 1991 & 23 \\
7 McDonald's (restaurants) & Taiwan, China & 1992 & 5 \\
McDonald's (restaurant) & Sydney River, Nova Scotia, Canada & 1992 & 3 \\
Brown's Chicken Restaurant & Palatine (Chicago), Illinois USA & 1993 & 7 \\
Sbarro (restaurant) & Jerusalem, Israel & 2001 & 15 \\
Paddy's Pub and Sari Club & Kuta Beach, Bali, Indonesia & 2002 & 202 \\
Maxim (restaurant) & Haifa, Israel & 2003 & 20 \\
International House of Pancakes & Carson City, Nevada USA & 2011 & 4 \\
Le Jardin (restaurant) & Kabul, Afghanistan & 2014 & 20 \\
several restaurants & Saint-Denis, France & 2015 & 130 \\
Ha' Simta (restaurant) & Tel Aviv, Israel & 2016 & 3 \\
Aziz Istanbul (restaurant) & Ouagadougou, Turkey & 2016 & 18 \\
Pulse (nightclub) & Orlando, Florida USA & 2016 & 49 \\
Black and Blue (restaurant) and & Borough Market, London UK & 2017 & 6 \\
Wheatsheaf Pub & & & \\
Total & & & 532 \\
\hline
\end{tabular}

Table 3 shows the list of restaurants and nightclubs/pubs in the world that have been scenes of terrorism by location, year, and the number of deaths involved. These tables show how frequently terrorist attacks occur at hotels, restaurants, or nightclubs. It is a small sample but reflects scenarios through time as well as the extent of the event. The reasons for some of the attacks are still unknown but include hate crimes, discrimination, and gained attention from the public.

The data makes it clear terror attacks at restaurants and nightclubs are devastating. The total number of these incidents was 17 in 10 countries resulting in 532 deaths. Five of the incidents occurred in the United States. The events with the least impact occurred at the McDonald's restaurant in Nova Scotia, Canada in 1992 and the Ha' Simta restaurant in Tel Aviv, Israel in 2016. Both of these incidents claimed three lives. In contrast, the simultaneous events at Paddy's Pub and the Sari Club at Kuta Beach in Bali, Indonesia in 2002 claimed 202 lives. The number of people injured was not considered as part of this research; however, the researchers acknowledge the numbers of injured are significant including 413 at Saint-Denis. Attacks 
on restaurants do not create as much national attention continuing to providing terrorists an easy access place to commit harm generating greater local attention (Goodwin, Kaniasty, Sun \& Ben-Ezra, 2017).

Table 3 shows the strategy used by properties attacked by terrorists. Strategies include rebranding, new ownership, bankruptcy, renovation, increased security, closure, and doing nothing. These strategies were compared by property types including hotels, nightclubs/pubs, and restaurants. These categories were totaled and are presented below:

TABLE 4

STRATEGIES OF HOTELS AND RESTAURANTS/NIGHTCLUBS/PUBS FOLLOWING A TERRORIST ATTACK IN VOLUME AND PERCENTAGE

\begin{tabular}{lllllll}
\hline Strategy & Hotel & $\%$ & $\begin{array}{l}\text { Restaurant/Night } \\
\text { Club/Pub }\end{array}$ & $\%$ & Combined & $\begin{array}{l}\% \\
\text { Difference }\end{array}$ \\
\hline Rebrand & 4 & 21.1 & 2 & 11.8 & 6 & 09.3 \\
New Ownership & 2 & 10.5 & 0 & 00.0 & 2 & 10.5 \\
Bankruptcy & 0 & 00.0 & 0 & 00.0 & 0 & 00.0 \\
Renovation & 2 & 10.5 & 0 & 00.0 & 2 & 10.5 \\
Increased Security & 15 & 78.9 & 1 & 05.9 & 16 & 73.0 \\
Closure & 2 & 10.5 & 9 & 52.9 & 11 & -42.4 \\
Do Nothing & 0 & 00.0 & 7 & 41.2 & 7 & -41.2 \\
Total & 19 & 100.0 & 17 & 100.0 & 36 & 00.0 \\
\hline
\end{tabular}

Table 4 shows the list of seven different possible strategies employed following a terrorist attack and by hospitality type. The measured strategies include: the rebranding of the institution such as a name change, whether a new owner was needed to survive, use of chapter 7 bankruptcy or chapter 13 reorganization, if a major renovation took place if security was increased if the institution closed or did none of the previous options was employed. After many attacks, it is expected some cleanup and fixes are being made. With Mandalay Bay, the hotel room used needed to be cleaned and windows needed to be repaired (Taylor, 2017). Some of the hotels where bombs were used need not only repairs but structural renovations could be costlier than a tear down with rebuild being a different structure (Yallop, 1980). Renovation involves whether those fixes were intended to change the appearance or style of the organization rather than "make the organization whole" by rebuilding in the previous style.

From the total column come interesting and possibly counter-intuitive results. These include the results of thirty-six entities including nineteen hotels and seventeen restaurants, nightclubs, and pubs. None of the entities attacked filed for bankruptcy. This includes the J. W. Marriott in Jakarta, Indonesia, and the Serena Hotel in Kabul, Afghanistan who were both victims of two attacks. Only two hotels or $10.5 \%$ changed owners. These include The Sheraton in Karachi, Pakistan, and The Riu Imperial Marhaba in Sousse, Tunisia. The Riu Imperial Marhaba changed both names and owners. The new owners are Steigenberger a German hotel group and they changed the name to Kantaoui Bay. Sixteen entities increased security and eleven closed.

There is a stark difference between strategies employed by hotels and those by restaurants and pubs. For example, fifteen, $78.9 \%$, out of nineteen hotels increased security while only one, $5.9 \%$, of seventeen restaurants did. The represents a difference of $73 \%$. The strategy most used by restaurants, nightclubs, or pubs was closure. Considering hotels, , the locations remain open as only two, $10.5 \%$, of the nineteen hotels closed. On the contrary, nine, $52.9 \%$, of the seventeen restaurants closed for a difference of $42.4 \%$. Three of the nightclub's closures involve destroying their structures and converting them into memorials. These include Pulse in Orlando, Florida USA, Paddy's Pub, and Sari in Bali, Indonesia. None of the hotels selected a "no strategy" while seven, $41.2 \%$, of the restaurants, nightclubs, or pubs did. On the end of extreme "no strategy" was one chain of seven McDonald's restaurants in Taiwan, China after they were attacked in synchronized attacks. 
The Sheraton hotel in Karachi rebranded to the Mövenpick Hotel. The Mövenpick Hotel decided to buy out the Sheraton hotel in hopes of improving its performance utilizing a non-American brand. Today it is still housing guests and increasing security in hopes another incident doesn't occur. Since Sheraton is an American company, the property owners thought it would increase the chances of an attack. The other three hotels that have rebranded are the Radisson in Amman, Jordan, The Regency Hotel in Dublin, Ireland, and the Riu Imperial Marhaba in Sousse, Tunisia. The Regency Hotel still has the same owners but changed the name to not carry the terrorist attack reputation. The owners of the Radisson rebranded to the Landmark Amman Hotel and Conference Center and have a 5-star rating, coming a far way since the attack on the hotel in 2005. The Riu Imperial Marhaba changed both name and owners.

The hotels that were attacked twice have paid the most attention to security. The JW Marriot, as well as Serena, was, unfortunately, a good source for a predator. In Jakarta, at the Marriott and Ritz Carlton hotels, terrorists took a new tactic of bringing in separate parts to a bomb and building it in the hotel. The other 2003 Marriot bombing in Jakarta was a car bomb. The JW Marriot is currently still in business but with much higher security tactics. After the 2003 attack, the Marriott increased security and with the 2009 attack, the hotel managers stated the only way they could have snuck anything in was if they did a suicide bomb which is not $100 \%$ foolproof (Breslawski, 2021). Overall, Marriott has been doing everything in its power to avoid another attack (Heonenmeyer, 2016).

After compiling the results of 15 hotels and 17 restaurants/ nightclubs, the overall majority decided to renovate their location and reopen. Usually, the areas remain open today and continue to operate, affording the losses created by the attacks through the support of corporate offices. Analyzing specific locations show how each handled its terrorist attack. The primary concern for cities remains how the broader surroundings are affected. A month after the Mandalay Bay shooting, the airlines in the US are down $21 \%$ and internationally decreasing by $16 \%$ (Silk, 2017). Las Vegas does not expect to continue to decline if no other incidents take place and these results show it is not just the specific hotel taking a hit, but how it affects the surrounding areas and broader industries serving the area. By connecting all hotel managers in the area with the police, it will improve the city as a whole.

Safety and security are now some of the most popular attributes hotel guests are looking for. Feeling safe will beat out any amenity the hotel has to offer. Even some of the new improvements the industry has made in technology including smart mirrors, tablet controls, virtual reality, RFID, and robots (Mandelbaum, 2016). These new gadgets were made with the intent to enhance guests' experience at the hotel, but these gadgets would never beat out feeling unsafe. Hotels often adjust help restore confidence for travels. These include: updating locks, having regular safety meetings, monitor all activities, meet and greet with all customers, and check for out of profile guests (Donaldson, 2013). Simple gestures and being aware of risks lessen the chance of the attack as well as make guests feel comfortable and want to come back. The unfortunate part about increasing technology is it improves experiences but also more high-tech items are being released aren't for the good of humanity. It's not only important for hotels to be up-to-date on improving technology but also technology can be turned into a disaster.

The next table shows the changes that will improve guests' experience in both tangible and intangible ways. This way there is a change that will attract all sorts of guests. Guests are looking for top-of-line technology features will be drawn to stay at your hotel as well as guests looking for the best proactive security. Having both sides covered in terms of guest's satisfaction, will, in turn, draw interest to the brand as well as an increase in revenue. 
TABLE 5

SECURITY MEASURES TAKEN AT HOTELS AND WAYS TO ENHANCE STAYS

\begin{tabular}{ll}
\hline Ways to Increase Hotel Security & Ways to Enhance Guests' Stay \\
\hline Update Locks & Smart Mirrors \\
Safety Meetings & Tablet Controls \\
Monitor Activities & Virtual Reality \\
Evaluate and Improve & RFID \\
Meet and Greet & Robots \\
Ownership & \\
Employee Empowerment & \\
Staff Smart & \\
Active Monitoring & \\
Connect IT and Security & \\
Upgrade to VLAN & \\
Social Engineering & \\
\hline
\end{tabular}

Security is a key measure for success within the hospitality industry since the Las Vegas shooting took place. Casinos are trying to ramp up security as they do not want to be the next establishment to have an incident. Between the financial burden, the decreased reputation, and the overall impact on victims and families, hotel managers have received an unwelcome wake-up call to change the way they handle everyday guests. Whether an attack is made by a bomb or shooting, the reactions are the same. This makes guest safety a priority for both those in the hospitality industry and for travelers (Pizam \& Fleischer, 2002).

\section{THEORETICAL CONTEXT}

In a theoretical concept of owning a hotel in Paris during the attack, an owner faces many concerns of this situation. One of the main concerns is people are not going to want to come back to the hotel. The latest assessment from wholesale hotel room buyer JacTravel, which fills 250,000 bed nights a year in Paris, shows bookings are down for this normally busy time (Canadian Travel Press, 2016). Tourists are one of the main sources of income for hotels in Europe. If tourists hear of this hotel being involved in such an attack, it will steer them away from planning a visit to stay there. Paris was changed by the attacks on November 13. Businesses are suffering because fewer people are going out and the volume of tourists has shrunken (Chesters, 2016). This comes with the question of, what can be done in ensuring these people keep coming back? A conclusion for this concern could be to increase security throughout the hotels. This type of bag and body search has become common in Paris and everyone is learning to live with the new restrictions. One shopper said: 'The security is making people more scared, but not making them feel any safer' (Chesters, 2016). The hotel is going to be known for the attack instead of what it has to offer. There needs to be an increase in promotion of what the hotel is precisely there for. Another threat to the hotel is having people flood in just to see the action of the attack rather than coming to enjoy their time.

To focus on something other than just the customers being a concern, there is a focus on the employees. Employees, if they were present during the attack, have experienced the trauma it put everyone through first hand. They know on a deeper level how much it has impacted the public. This all comes to the inquiry of situations such as, what happens if employees start to quit their jobs because they do not want to be involved in another situation like this? If this burden were to come about, the result is having to search for new people who are willing to have this job and replace the others.

With all the entanglements above being said, it comes with an even deeper concern. Without the customers and employees, the hotel and the owner are going to lose a significant amount of money. The owners come to the possible questions of, how is the mortgage going to be paid? Am I going to lose the hotel? What happens next? There is no telling how much money is going to go towards keeping the hotel 
up and running normally. Not to mention the money is going to have to be put out to repair the damages from the attack.

\section{CONCLUSIONS, LIMITATIONS, AND FUTURE RESEARCH}

This research sought to answer the questions: "Can suggestions be made to help MGM Resorts International decide strategies following the mass shooting at its Mandalay Bay Resort and Casino located in Las Vegas to survive?" The second question is "Can the hospitality industry apply these strategies in the future?"

The research looks at many different aspects when it came to terrorist attacks. First, researchers compiled a list of attacks including venue type such as hotel, restaurant, and nightclub/pub; city, state, country location; year; and severity as defined by the number of individuals dying. Researchers then searched the web to see what response these entities had to the attack to develop a conclusion on how Mandalay Bay should react.

Several conclusions were reached from this research. These include understanding natural time frames in recovery, engaging the city of Las Vegas, being proactive, increasing security, and repairing the damaged reputation. It is expected Mandalay Bay hotel will make a full financial recovery. This event will forever be a mark on the organization's reputation and history.

\section{Strategies for Mandalay Bay}

First, executives need to understand the natural timeframe for recovery. This means when a sudden drop in visitors occurs, not overreacting. Findings show there is a natural nine-month recovery cycle. In the long run, guests rarely blame the establishment for the crimes of a guest. Visitors just want to be assured their safety is addressed. This knowledge also encourages management to not undertake expensive renovations that may not be necessary.

Second, engaging the city of Las Vegas. The impact of this disaster is not isolated to one hotel. The city of Las Vegas is an actively engaged city when promoting tourism. The city temporally halted marketing the slogan "What happens in Vegas, Stays in Vegas." Mandalay Bay should continue to engage the city to ensure maximum benefit. This marketing change should occur until there until visitor perceptions return to a more traditional Las Vegas style vacation. Also, the city should increase visible security in the short-term (Hagerty, 2017). This is done to ensure visitors and potential visitors the city is serious about their safety. Last, the hotels working with the city should determine if regulations on monitoring visitors and their rooms are necessary. The reason regulation may be needed is to ensure hotels that add extra procedures for safety aren't put at a competitive disadvantage to those that do not.

Third, being proactive. Few of the organizations impacted by a tragedy did anything. The one organization that did nothing was a unique situation. In this situation, there were seven McDonald's restaurants impacted. None of the deaths happened inside a location. Additionally, the person planting the bomb was out to extort $\$ 240,000$ from the chain. As a result, the chain closed all fifty-seven of its restaurants until the police could investigate (Reuters, 1992). As a result, it was determined this incident was more of criminal activity rather than terroristic. Mandalay Bay should also do everything in its power to limit negative coverage of the hotel in the media. This includes a careful screening of conventions for both security and reputational risks. For example, the hotel should strongly consider the ramifications of hosting a "gun show" for a while.

Fourth, Mandalay Bay should increase security. Mandalay Bay, as well as all other casinos, are taking proactive approaches to security to prevent or deter future attacks. This security should include both securing the building and the monitoring of guests as they come and go from the building. Though it is customary for these hotels to have extensive camera coverage, the hotel should consider adding more cameras at the top of the building to better monitor external activities. Mandalay Bay should, at least in the short term, remove "do not disturb" signs and require each room to be inspected by employees every day.

Fifth, repair the damaged portion of the hotel and limit access. The windows to the exterior of the building need to be repaired such that the room cannot be identified by a slight difference in color at times 
caused by new windows. On completion of all investigative work the thirty-second floor it should remain unrented for some time. A plan of action should be in place on future room rentals for this floor which would allow for other rooms on the floor to be rented out while limiting "sightseeing" and possible "memorials" to the shooter.

\section{Hospitality Industry Application}

This research concludes terrorist attacks have rippling effects on the hospitality industry. The industry must take a proactive approach rather than the common reactive approach. As stated earlier in the research, it is noted the casino and hotel industries have weak security protocols. This weakness is what led up to the Mandalay Bay attack. The shooter was able to easily search venues and, without detecting or raising any concern, amass large amounts of weapons and ammunition. Enacting security should be done by understanding the possible impact on customers, though some small measures could be completed at a minimal cost. For example, overseeing the baggage brought into and leaving facilities, engaging daily room checks and visible security could go a long way in preventing future incidents. For cities, monitoring the response of cities involved in previous attacks could serve as a risk management technique by reminding areas to be vigilant. These prior experiences could serve also as a knowledge base if an attack does happen. Although there is no one strategy to fully limit future terrorist attacks, there is planning that can be done in the best hopes to prevent it. While increasing security benefits for guests' safety is the most important, it is also important to improve the hotel to attract guests and increase revenue. By adding features such as guest meet and greet and virtual reality, will take the focus off security and focus on the new technology and attractions which will improve guests' experience and return rate.

\section{Research Limitations}

There are several limitations to this study. These include not having firsthand accounts of events and data was obtained via sources may be less than ideal. For example, to determine if a faculty was remodeled, images available on Google.com were used to identify changes. Additionally, most organizations do not disclose their security strategies. Researchers needed to search news sources to decide if security was increased. Another issue was some sources reported conflicting statistics. For example, defining an injury and counting deaths when the event occurred can impact the numbers reported. The name of one hotel the Kabul Intercontinental showed inconsistency with its spelling. Some sources identified it as "intercontinental" while others used "Inter-continental." Also, eyewitness accounts are not reliable and there is difficulty determining responses made by each location of the attack. A final reason is cities and businesses want to keep the events out of the media to minimize negative coverage.

\section{Future Research}

This research lends itself to a great deal of future research and should proceed full steam ahead. Businesses are looking for ways to become proactive, and the best way to do this is to study the past and see where mistakes have happened. Major hotels and restaurant chains could be studied to determine the best manner to proactively work to prevent attacks. This is especially true in vulnerable areas. Also, as technology becomes more advanced there will be new ways developed for screening guests and their baggage to detect ammunition or bomb-making materials. 


\section{REFERENCES}

Alderman, L. (2016, July 29). Terrorism scares away the tourists Europe was counting on. Retrieved from https://www.nytimes.com/2016/07/30/business/international/europe-economy-gdpterrorism.html

Breslawski, J. (2021). A new wave of terror. Political Violence at a Glance. Retrieved from https://politicalviolance.org/2021/02./11/a-new-wave-of-terrorism

Cano, R.G. (2017, October 16). Las Vegas tourism sees changes in aftermath of the shooting. Retrieved February 5, 2018, from http://www.chicagotribune.com/business/ct-biz-las-vegas-tourismchanges-20171016-story.html

Craig, T., Berman, M., Barrett, D., \& Zapotosky, M. (2017, October 3). Police sat Las Vegas gunman planned "extensively," used camersa to monitor as they approached. The DailyRepublic.com.

DeMers, J. (2016, July 8). 5 Examples of Rebranding Done Right. Retrieved from https://www.forbes.com/ sites/jaysondemers/2016/07/07/5-examples-of-rebranding-doneright/\#566cc7d0385a

Donaldson, D. (2013, November 12). 12 ways to increase hotel security. Lodging Magazine. Retrieved from: http://lodgingmagazine.com/ways-to-increase-hotel-security/

Feehan, C. (2017, October 7). Dublin's Regency hotel given re-brand after Kinahan feud shooting. Belfast Telegraph. Retrieved from http://www.belfasttelegraph.co. uk/news/republic-of-ireland/dublinsregency-hotel-given-rebrand-after-kinahan-feud-shooting-36205411

Glaeser, E.L., \& Shapiro, J.M. (2001). Cities and warfare: the impact of terrorism on urban form. Cambridge, MA.: National Bureau of Economic Research, c2001.

Goodwin, R., Kaniasty, K., Sun, S., \& Ben-Ezra, M. (2017). Psychological distress and prejudice following terror attacks in France. Journal of Psychiatric Research, (91), 111-115. doi:10.1016/j.jpsychires.2017.03.001

Hagerty, K. (2017, October 3). Hotel security in the spotlight after deadly Las Vegas shooting. Retrieved from https://www.forbes.com/sites/bisnow/2017/10/03/hotel-security-in-the-spotlight-afterdeadly-las-vegas-shooting/\#4a06360d34cc

Heonenmeyer, L. (2016, January 22). Marriott CEO weighs impact of terrorism on hotel industry. Retrieved from https://www.cbsnews.com/news/marriott-ceo-weighs-impact-of-paris-terrorattacks-on-hotel-industry/

Holland, M.J. (2003). Puzzle of Defining Bodily Injury under the Warsaw Convention. Defense Counsel Journal, (4), 424-432.

Kitchen, T. (2001). Planning in response to terrorism: The case of Manchester, England. Journal of Architectural and Planning Research, (4), 325-340. Retrieved from https??www.jstor.org/stable/43031048?drq=1\#metadata_info_tab_contents

Koroma, A. (2011). The ongoing effect of terrorism on the hospitality and tourism industry. Retrieved from https://cardinalscholar.bsu.edu/bitstream/handle/123456789/194819/koromaA_20112_body.pdf?sequence $=1$

Mandelbaum, A (2016, April 26). 5 gadgets to enhance the guest stay. Lodging Magazine. Retrieved from: http://lodgingmagazine.com/5-gadgets-to-enhance-the-guest-stay/

Matousek, M. (2017, December 29). Disney got rid of the 'do not disturb' signs at its hotels - and the reason is chilling. Business Insider.

Montero, D. (2017). Las Vegas' delicate balancing act: Promoting tourism while acknowledging mass shooting. L.A. Times. Retrieved from http://www.latimes.com/nation/la-na-vegas-shooting-ad20171027-story.html

Moore, T. (2017, November 12). Mandalay Bay staff reduction result of Oct. 1 shooting attack. Retrieved February 6, 2018, from https://lasvegassun.com/news/2017/nov/12/mandalay-bay-staff-reductionresult-of-oct-1-shoot/

O Brien, K.A. (2009). Managing national security and law enforcement intelligence in a globalised world. Review of International Studies, 35(4). doi: 1017/S0260210509990349 
Ollila, J. (2016, December 13). Sheraton Brussels Bankruptcy \& Starwood Affiliation Ends on December 31, 2016 (Terrorism \& Asbestos Problems). Retrieved from

https://loyaltylobby.com/2016/12/13/sheraton-brussels-bankruptcy-starwood-affiliation-ends-ondecember-31-2016-terrorism-asbestos-problems/

Palazzolo, J., \& Elinson, Z. (2017, October 2). Las Vegas gunman had arsenal in hotel room. The Wall Street Journal. Retrieved from https://www.wsj.com,/articles/las-vegas-suspect-likely-usedautomatic-rifle-in-massacre-1506966716

Paris Hotels Suffer After Terrorist Attacks. (2016). Canadian Travel Press, 48(15), 6-10. Retrieved from https://hospitality-on.com/en/activieites-hotelieres/terrorist-attacks-paris-impact-hotel-industry.

Pizam, A., \& Fleischer, A. (2002). Severity versus frequency of acts of terrorism: Which has a larger impact on tourism demand? Journal of Travel Research, 40(3), 337-339.

Doi:10.1177/0047287502040003011

Reuters. (1992, April 30). McDonald's Closes in Taiwan after string of bomb attacks. Retrieved from NYTimes.com

Ross, E. (2017, June 2). Trump calls casino fire a 'terrorist attack,' causing laughter among officials. Retrieved from http://www.newsweek.com/trump-calls-philippines-casino-fire-terrorist-attack619528

Shan, L. (2017, October 2). The owners of Mandalay Bay lost almost a billion dollars in value after Las Vegas shooting. Retrieved from http://fortune.com/2017/10/02/ las-vegas-shooting-mandalaybay-mgm-stock/

Silk, R. (2017, November 13). Las Vegas tourism reeling from mass shooting. Retrieved from http://www.travelweekly.com/North-America-Travel/Las-Vegas-tourism-reeling-from-massshooting

Stickel, E.A. (2011). Predictor's of terrorism-related air travel reduction and associated tourism impacts. Tourism Analysis, 16(5), 623-631. https://doi.org/10.3727/108354211X13202764960861

Taylor, K. (2017, October 11). A 21-year-old who was shot in the chest during the Las Vegas shooting is suing the Mandalay Bay hotel. Retrieved from http://www. businessinsider.com/las-vegas-victimlawsuit-2017-10

Taylor, K. (2017, October 12). Mandalay Bay just denied a claim that victims are using to blame the hotel for the Las Vegas shooting. Retrieved from http://www. businessinsider.com/mandalay-bayresponse-las-vegas-shooting-timeline-concerns-2017-10

U.S. Code. (2017). Domestic terrorism. Legal Information Institute - Cornell University Law. Retrieved from https://www.law.cornell.edu/uscode/text/18/2331

Viola, D.C. (2018). Terrorism and the response to terrorism in New York City during the long sixties. Dissertation Abstracts International Section A, pp. 78-82.

Voice of America. (2017). Orlando tourism grew in 2016, Despite tragic headlines. Retrieved from https:/www.voanews.com/a/orlando-tourism-grew-in-2016-despite-tragicheadlines/3848377.html

Yallop, H.J. (1980). Protection Against Terrorism. Protection Against Terrorism, pp. 97-99. Retrieved from https://assets.publshing.service.gov.u/government/upoads/attachment_data/file/62120/protectingagainst-terrorism-3rd-edition-pdf 


\section{APPENDIX}

TABLE 1

DATA FOR HOTELS, RESTAURANTS AND NIGHTCLUBS/PUBS ATTACKED BY TERRORISTS WORLDWIDE

\begin{tabular}{|c|c|c|c|c|c|c|c|}
\hline Hotel & Rebr & Nwn & Bank & Renov & Secur & Close & Noth \\
\hline Sheraton ( $1^{\text {st }}$ floor renovate) & Yes & Yes & & & Yes & No & No \\
\hline $\begin{array}{l}\text { J W Marriott (1) ( } 1^{\text {st }} \text { floor } \\
\text { destroyed) }\end{array}$ & No & No & No & No & Yes & No & No \\
\hline Hilton & No & No & No & No & Yes & No & No \\
\hline Grand Hyatt,...Rd...DI & Yes & No & No & No & Yes & No & No \\
\hline GH...Radisson... DI & No & No & No & No & Yes & No & No \\
\hline GH...Rd...Days Inn & No & No & No & No & Yes & No & No \\
\hline $\begin{array}{l}\text { Hard Rock Jimbaran Bch. } \\
\text { Resort }\end{array}$ & No & No & No & Yes & No & No & No \\
\hline Marriott (Barbed wire) & No & No & No & No & Yes & No & No \\
\hline Taj and $\mathrm{O} \mathrm{H}$ & No & & No & No & Yes & No & No \\
\hline Taj and Oberoi Hotels & No & & No & No & Yes & No & No \\
\hline Serena (1) & No & & & No & Yes & No & No \\
\hline $\mathrm{J}$ W Marriott (2)... RC & No & No & No & No & Yes & No & No \\
\hline $\begin{array}{l}\text { J W M...Ritz Carlton (new } \\
\text { building) }\end{array}$ & No & No & No & Yes & Yes & $\begin{array}{l}\text { Yes } \\
\text { (const) }\end{array}$ & No \\
\hline Pearl Continental & No & No & No & No & Yes & No & No \\
\hline Serena (2) & No & & & No & Yes & No & No \\
\hline Radisson Blu & No & No & No & No & Yes & No & No \\
\hline Riu Imperial Marhaba & Yes & Yes & No & No & No & Yes $(2 y)$ & No \\
\hline Corinthia Hotel & No & No & No & No & Yes & No & NO \\
\hline Regency Hotel & Yes & & & & & & \\
\hline SUBTOTAL & 4 & 2 & 0 & 2 & 15 & 2 & 0 \\
\hline Chez Jo Goldenberg Rest. & No & No & No & No & & No & \\
\hline $\begin{array}{l}\text { McDonald's (restaurant) } \\
\text { (rebuilt down road) }\end{array}$ & Yes & No & No & No & No & Yes & No \\
\hline Luby's Cafeteria & No & No & No & No & Yes & $\begin{array}{l}\text { Yes } \\
\text { (5 months) }\end{array}$ & No \\
\hline 7 McDonald's (restaurants) & No & No & No & No & No & No & Yes \\
\hline $\begin{array}{l}\text { McDonald's (restaurant) } \\
\text { (rebuild down road) }\end{array}$ & Yes & No & No & No & No & Yes & No \\
\hline $\begin{array}{l}\text { Brown's Chicken Rest. }(35 \% \\
\text { decrease in sales) }\end{array}$ & No & No & No & No & No & $\begin{array}{l}\text { Yes } \\
\text { (100 rests) }\end{array}$ & No \\
\hline Sbarro (restaurant) & No & No & No & No & No & Yes & No \\
\hline $\begin{array}{l}\text { Paddy's Pub ... S C } \\
\text { (memorial) }\end{array}$ & No & No & No & No & No & Yes & No \\
\hline P P ... Sari Club (peace park) & No & No & No & No & No & Yes & No \\
\hline $\begin{array}{l}\text { Maxim (restaurant) (memorial } \\
\text { closeby) }\end{array}$ & No & No & No & No & No & No & Yes \\
\hline $\begin{array}{l}\text { Internat'l House of Pancakes } \\
\text { (temp memorial) }\end{array}$ & No & No & No & No & No & No & Yes \\
\hline $\begin{array}{l}\text { Le Jardin (restaurant) } \\
\text { several restaurants }\end{array}$ & No & No & No & No & No & No & Yes \\
\hline
\end{tabular}




\begin{tabular}{llllllll}
\hline Ha' Simta Theatre "the Alley & No & No & No & No & No & Yes & No \\
Bar" (restaurant) & & & & & & & \\
Aziz Istanbul (restaurant) & No & No & No & No & No & No & Yes \\
Pulse (night club) (memorial) & No & No & No & No & No & Yes & No \\
Black/Blue ... Wheatsheaf & No & No & No & No & No & No & Yes \\
B/B ... Wheatsheaf & No & No & No & No & No & No & Yes \\
\hline Subtotal & 2 & 0 & 0 & 0 & 1 & 9 & 7 \\
\hline Total & 6 & 2 & 0 & 2 & 16 & 11 & 7 \\
\hline
\end{tabular}

